\title{
Impact of the Interaction of Hepatitis B Virus with Mitochondria and Associated Proteins
}

\author{
Md. Golzar Hossain 1,2,*(D), Sharmin Akter ${ }^{3}$, Eriko Ohsaki ${ }^{1}$ (D) and Keiji Ueda ${ }^{1, *}$ \\ 1 Division of Virology, Department of Microbiology and Immunology, Graduate School of Medicine, \\ Osaka University, Osaka 565-0871, Japan; eohsaki@virus.med.osaka-u.ac.jp \\ 2 Department of Microbiology and Hygiene, Bangladesh Agricultural University, \\ Mymensingh 2202, Bangladesh \\ 3 Department of Physiology, Bangladesh Agricultural University, Mymensingh 2202, Bangladesh; \\ sharmin.akter@bau.edu.bd \\ * Correspondence: mghossain@bau.edu.bd (M.G.H.); kueda@virus.med.osaka-u.ac.jp (K.U.)
}

Received: 16 December 2019; Accepted: 3 February 2020; Published: 4 February 2020

\begin{abstract}
Around 350 million people are living with hepatitis B virus (HBV), which can lead to death due to liver cirrhosis and hepatocellular carcinoma (HCC). Various antiviral drugs/nucleot(s)ide analogues are currently used to reduce or arrest the replication of this virus. However, many studies have reported that nucleot(s)ide analogue-resistant HBV is circulating. Cellular signaling pathways could be one of the targets against the viral replication. Several studies reported that viral proteins interacted with mitochondrial proteins and localized in the mitochondria, the powerhouse of the cell. And a recent study showed that mitochondrial turnover induced by thyroid hormones protected hepatocytes from hepatocarcinogenesis mediated by HBV. Strong downregulation of numerous cellular signaling pathways has also been reported to be accompanied by profound mitochondrial alteration, as confirmed by transcriptome profiling of HBV-specific CD8 T cells from chronic and acute $\mathrm{HBV}$ patients. In this review, we summarize the ongoing research into mitochondrial proteins and/or signaling involved with HBV proteins, which will continue to provide insight into the relationship between mitochondria and HBV and ultimately lead to advances in viral pathobiology and mitochondria-targeted antiviral therapy.
\end{abstract}

Keywords: Hepatitis B virus (HBV); mitochondria; proteins/signaling; interaction

\section{Introduction}

Mitochondria are double-membraned organelles of eukaryotic cells. The basic structure of the mitochondrion is composed of an outer mitochondrial membrane (OMM), inner mitochondrial membrane (IMM), intermembrane space, cristae, and matrix. There are 1000-2000 different proteins in the mitochondria [1]. The most important functions of mitochondria are to generate energy, regulate cell metabolism, and transmit calcium signaling to other organelles in the cells. Mitochondria also play crucial roles in cell apoptosis [2]. The OMM can associate with the membrane of the endoplasmic reticulum (ER), resulting in a structure called the mitochondria-associated ER-membrane (MAM). This communication is important for calcium signaling between the OMM and ER [3]. The number of mitochondria varies dependent on the cell types. Liver cells contain 500-4000 mitochondria per cell [4]. One study suggested that mitochondria play important roles in the innate immune system against viral infection through the mitochondrial antiviral signaling protein (MAVS) [5].

Mitochondria can change their shape and location, and can undergo fusion, fission, and mitophagy in response to cellular stresses in order to maintain homeostasis [6]. These mitochondrial dynamics might be dependent on different pathological conditions, such as cancers and viral infection [6-8], 
and many viruses-including hepatitis $B$ virus (HBV), hepatitis $\mathrm{C}$ virus (HCV), pseudorabies virus, human cytomegalovirus (HCMV), Epstein-Barr virus (EBV), influenza A virus, measles virus, Newcastle disease virus (NDV), and SARS corona virus [6] - may interfere with the mitochondrial dynamics. These viruses have been found to interact with many mitochondrial proteins and disrupt mitochondrial dynamics, resulting in cellular apoptosis, intracellular calcium signaling, and innate immune signaling [6].

HBV is a partially double-stranded DNA virus belonging to the family of hepadnaviridae, and causes an acute and chronic liver disease known as hepatitis B (HB) $[9,10]$. HBV contains a $3.2 \mathrm{~kb}$ genome surrounded by an icosahedral capsid and an envelope. Its genome encodes four overlapping open reading frames (ORFs) known as polymerase (pol; $\mathrm{P})$, surface or envelopes (S), core (C), and $\mathrm{X}$ protein (X) (Figure 1) [11-14]. HBV enters hepatocytes through sodium taurocholate cotransporting polypeptide (NTCP) as a receptor to bind with the preS1 region in the envelope protein, and then the uncoated nucleocapsid is transported to the nucleus, where the relaxed circular DNA (rcDNA) genome is converted to covalently closed circular DNA (cccDNA) [15-17]. The cccDNA is competent for transcription of $3.5 \mathrm{~kb}$ pregenomic RNA (pgRNA), and for transcription of several subgenomic RNAs such as $2.4 \mathrm{~kb}$ preS-S mRNA, $2.1 \mathrm{~kb} \mathrm{~S}$ mRNA, and $0.7 \mathrm{~kb}$ X mRNA. The pgRNA is encapsidated together with pol and then reverse- transcribed into negative strand DNA, resulting in the formation of rcDNA. This newly formed nucleocapsid re-enters the nucleus as a result of intracellular cycling $[17,18]$.

A

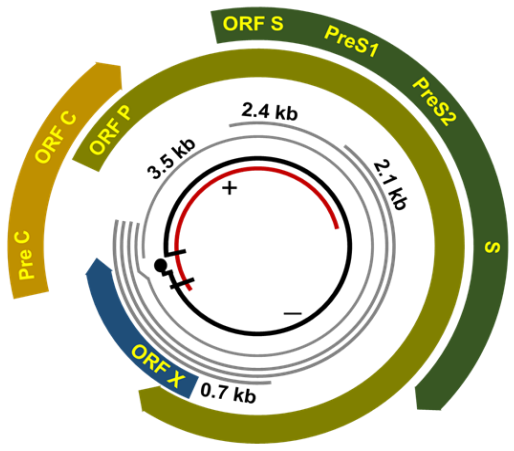

B

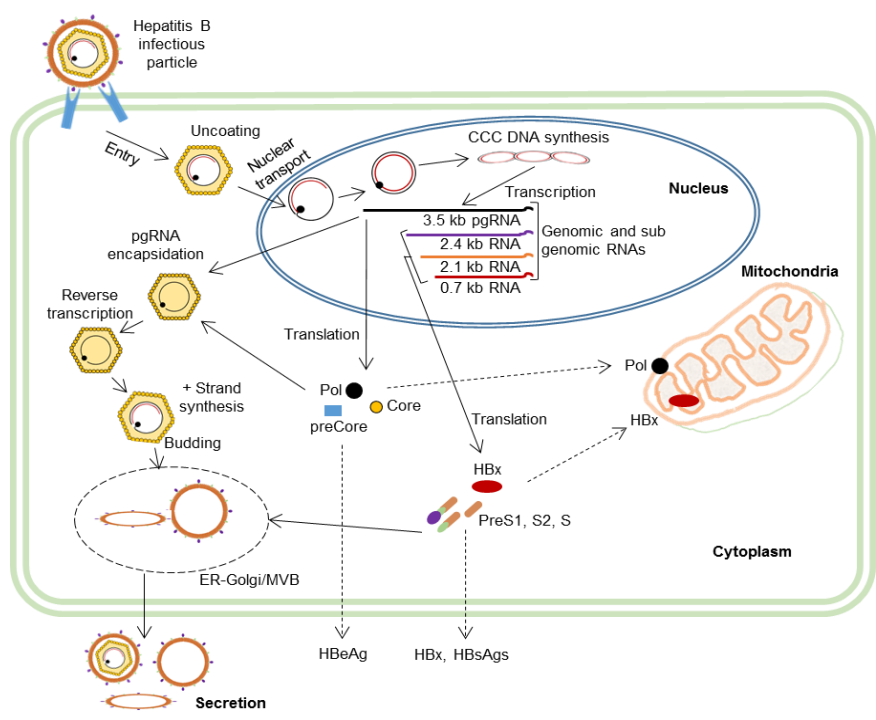

Figure 1. Hepatitis B virus (HBV) genomic map and an overview of the HBV life cycle. (A). HBV genomic map. The partially double-stranded DNA encodes four overlapping open reading 
frames (ORFs), preC-C, P, preS-S, and X. The ORF P overlaps the other three open reading frames (ORFs). (B). An overview of the HBV life cycle. HBV infects hepatocytes through preS1-NTCP interaction followed by uncoating and is transported to the nucleus where cccDNA is formed. The cccDNA acts as a template for transcription of the $3.5 \mathrm{~kb}$ pregenomic RNA (pgRNA), and the $2.4 \mathrm{~kb}, 2.1 \mathrm{~kb}$, and $0.7 \mathrm{~kb}$ subgenomic RNAs. The pol translated from pgRNA is encapsidated along with pgRNA, then reverse-transcribed, and the partially double-stranded DNA genome is formed. The core particle is enveloped in ER-Golgi/MVB and secreted into the extracellular space.

HBV encounters many subcellular organelles and host factors/proteins during the viral life cycle, including those involved in entry, nuclear transport of capsids, DNA replication, assembly, and egress [19]. HBV also targets mitochondria and disrupts mitochondrial dynamics, and several viral proteins localize at the mitochondria and interact with numerous mitochondrial proteins [7,20-23].

Recently, host factors involved in mitochondrial turnover have also been targeted for the HBV treatment [24]. Therefore, it would be useful to elucidate further details and basic information about the relationship between $\mathrm{HBV}$ and mitochondria. In this review, we summarize and discuss the recent literature on the interaction of mitochondrial factors and HBV gene products.

\section{Methods}

We comprehensively reviewed published articles related to HBV and mitochondria, and associated proteins. The key words we used to search the literature were "hepatitis B virus and mitochondria", "HBx and mitochondria", "HBV polymerase and mitochondria", "HBsAg and mitochondria", "HBV core and mitochondria", "preS1 and mitochondria", and so on. The related articles cited in the searched articles were also reviewed.

\section{HBV and Mitochondria}

It was reported that leakage of endoplasmic reticulum (ER)-calcium stores was caused by ERstress on HBV infection and adjacent depolarized and/or dysfunctional mitochondria, leading to ROS generation [25]. It was also reported that HBV might alter mitochondrial dynamics, leading to mitochondrial injury of hepatocytes, and subsequently liver disease onset $[7,25]$.

\section{1. $H B x$}

HBx is a multifunctional protein encoded by ORF $X$ and enhances HBV replication [26]. It activates various cellular transcription factors and plays roles in cell cycle regulation, calcium signaling, DNA repair, apoptosis regulation, ROS regulation, etc. [26-28]. Many studies reported that HBx is localized in mitochondria, either in the OMM, IMM, or matrix [29-33]. It has been demonstrated that the C-terminal transactivation domain of $\mathrm{HBx}$ [34] and the amino acids 54 to 70 of $\mathrm{HBx}$ [30] are involved in its mitochondrial localization in Huh7 and WRL68 cells transiently transfected with tagged based HBx, as shown by immunofluorescence analyses (IFA). This mitochondrial localization of HBx has been further confirmed by mitochondrial purification assay from HepG2 2.2.15 cells, a cell line persistently expressing a dimer molecule of HBV DNA under the control of native promoter [30]. Clippinger and Bouchard demonstrated that HBx was partially localized at the OMM in primary rat hepatocytes and HepG2 cells transfected with HBx and it regulates mitochondrial membrane potential $(\Delta \psi \mathrm{m})$ and activated NF- $\mathrm{kB}$ [32]. However, it is still unclear how mitochondria-associated HBx regulates HBV replication.

HBx induces production of reactive oxygen species (ROS), including mitochondrial ROS (mROS). Increased mROS damages mitochondrial DNA (mtDNA) that might play a role in hepatocellular carcinoma (HCC), and HBx-mediated ROS generation activates transcription factors such as Foxo-4 in Chang cells stably expressing $\mathrm{HBx}$ (Chang-HBx) and in primary hepatic tissues from HBx-transgenic mice; STAT-3, as well as NF-kB in HBx-transfected HepG2 cells [27,35-37]. Alteration of mtDNA has been reported in chronic HBV patients, and could be associated with HCC [38-41]. Chen et al. 
found significantly higher mtDNA in peripheral blood leukocyte (PBL) of chronic hepatitis B patients compared with a healthy control [39]. Moreover, higher mtDNA have been quantified in serum samples of HBV patients but revealed increased risk of HCC development with lower mtDNA level [38]. Zhao et al. also reported that lower mtDNA in PBL lead to increased risk of HCC [40]. The mtDNA copy number in HCC tissue samples correlated with large tumor size and liver cirrhosis [42]. A recent clinical study detected considerably higher mitochondrial superoxide in the cells of chronically infected patients and found extensively altered mitochondria [43]. Increased intrahepatic lipid peroxidase has been also reported in HBx-transgenic mice [44]. HBx directly binds with Raf- 1 and stimulates its translocation to mitochondria in Huh7 cells transfected with pCMV4X, suggesting that mitochondrial Raf-1 should protect cells from apoptotic stress [45]. Several studies showed that HBx colocalized with COXIII, an inner mitochondrial membrane protein, and upregulated its expression in HepG2 cells, and that HBx elevated ROS and altered mitochondrial biogenesis and morphology [46-49]. Endogenous COXIII colocalized with HBx in HepG2 cells generated by lentivirus transduction, which leads to the upregulation of COX-2 expression, thereby promoting cell growth [46]. HL-7702 cells stably expressing HBx generated by lentivirus transduction (HL-7702-HBx) led to swollen mitochondria, as shown by transmission electron microscopy [49]. Yoo et al. analyzed the subcellular distribution of HBx-Flag in Huh7 cells by confocal microscopy at different time points after transfection [50]. At $24 \mathrm{~h}$ after transfection, the HBx was found to be localized mainly in the nucleus and partly in the cytoplasm. However, HBx accumulated in the cytoplasm and in mitochondria at $36 \mathrm{~h}$, and more than $50 \%$ of the HBx localized into mitochondria as dot-like aggregates at $48 \mathrm{~h}$ after transfection. A mitochondrial E3 ubiquitin ligase, MARCH5 interacted and colocalized with $\mathrm{HBx}$ in mitochondria and promoted the degradation of $\mathrm{HBx}$ aggregates by polyubiquitination in Huh7 cells co-transfected with Myc-MARCH5 and mitochondria-targeted HBx (HBx-Mito-Flag) [50]. MARCH5 localized on OMM and regulated mitochondrial dynamics by ubiquitinating several mitochondrial proteins such as Drp1, Fis1, and Mfn1. MARCH5 along with Mfn1 maintain mitochondrial homeostasis and cell survival [51-54]. Moreover, MARCH5 decreased the HBx-induced NF- $\mathrm{kB}$ and COX-2 activity which may play important roles in carcinogenesis $[50,55,56]$. The authors further demonstrated that MARCH5 mRNA and protein expression in either HCC or HBV-mediated HCC liver tissue specimens of clinical cases were significantly downregulated in a later stage (Stage IV) of cancers with high expression of HBx [50]. In addition, AIM2 (absent in melanoma2) protein could be involved in cell proliferation and tumorigenic reversion and Aim2 deficient mice are more susceptible to the development of colonic tumor [57,58]. HBx reduced the expression of AIM2 which leads to HCC metastasis through the activation of EMT (epithelial-mesenchymal transition) by increasing expression of mesenchymal markers, vimentin, and N-cadherin and decreasing expression of E-cadherin, an epithelial marker in AIM2-overexpressed Bel-7402 and SMMC-7721 cells [59]. These results strongly correlated with the clinical cases as AIM2 expression has been found at significantly low level in tissues of HCC patients [59].

Many reports have suggested that HBx induces apoptosis. Takada et al. reported that HBx strongly interacted with p53 in the aggregated mitochondrial structure in tranfected Huh7 cells, probably at the OMM, and led to cell death [29]. Other reports suggested that HBx interacted with the human voltage-dependent ion channel (hVDAC3), which is an outer mitochondrial protein, and decreased $\Delta \psi \mathrm{m}$ of transfected HepG2 cells and cultured primary rat hepatocytes, thereby leading to cell death $[21,22]$. HBx increases cytosolic calcium by regulating the hVDAC component, mitochondrial permeability transition pore (MPTP) of HepG2 cells transfected with an HBV replication competent plasmid payw1.2 under control of endogenous promoter [60,61]. Moreover, HBx interacts with endogenous Bax in HepG2 cells stably expressing HBx, which acts as a pro- apoptotic regulator, and enhances the translocation of Bax to mitochondria, the release of cytochrome $\mathrm{c}$, and the induction of apoptosis [62,63]. Bax itself also interacts with hVDAC and causes a reduction of $\Delta \psi \mathrm{m}$ and release of cytochrome c [31,33]. Cardiolipin (CL), a mitochondrial lipid, is predominantly located at IMM and plays important roles in mitochondrial functions, including apoptosis and mitophagy [64]. You et al. 
demonstrated that $\mathrm{HBx}$ bound with CL and increased membrane permeabilization [65]. However, Lee et al. reported that HBx did not activate apoptotic signaling in transfected HepG2 cells though it increases mROS [44], and none of these above studies showed the involvement of mitochondria.

HBx upregulates the expression of mitochondrial serine/threonine-protein kinase (PINK1) [7]. PINK1 is localized at the OMM, and it selectively accumulates on the depolarized/dysfunctional mitochondria and recruits parkin to destroy these mitochondria [66]. Parkin ubiquitinates mitochondria-associated HBx to trigger selective mitophagy. HBx stimulates parkin translocation to mitochondria for degradation of Mfn2 by ubiquitination in a PINK1/parkin-dependent manner in HBV-replicating Huh7 cells transiently transfected with 1.3 mer HBV genome under the control of native promoter [7]. Mfn2 is an outer mitochondrial membrane protein and plays a vital role for mitochondrial fusion. Kim et al. demonstrated that HBV and its encoded HBx protein promoted mitochondrial fragmentation (fission) via Drp1 stimulation, and mitophagy via parkin, PINK1, and LC3B stimulation [7]. They also demonstrated that HBx-induced mitophagy to attenuate mitochondrial apoptosis, suggesting that HBV-induced mitochondrial fission and mitophagy should facilitate cell survival and viral persistence. Huang et al. reported that HBx-induced mitophagy through the PINK1-parkin pathway by increasing mitochondrial LONP1, which plays roles in the unfolded protein response (UPR) in the mitochondrial matrix. This phenomenon has been confirmed in HBV-replicating HepG2.2.2.15 cell line $[67,68]$. Chi et al. investigated the mitochondrial localization of HBx with its effect on mROS and $\Delta \psi \mathrm{m}$, which correlated with their data from HBx transgenic mice and clinical HBV-mediated HCC patients [69]. HBx-induced carcinogenesis in HBx transgenic mice and predominantly localized into mitochondria in stably expressing HepG2 cells and interacted with PINK1 and parkin [69]. Thyroid hormone (TH) simultaneously induces mitochondrial biogenesis and autophagy of HBx-targeted mitochondria through PINK1 induction to suppress HBx-promoted ROS generation and carcinogenesis [69]. They further demonstrated that TH abolished HBx-mediated upregulation of transcription factors, phospho-STAT3, c-Jun, NF- $\mathrm{KB}$, and AP-1 through the increase of mROS and the reduction of $\Delta \psi \mathrm{m}$, and these results are consistent with others reports $[35,37,69]$. These TH/PINK1/Parkin signaling effects on the reduction of HBx- mediated HCC are correlated with clinical cases [69]. HBx promotes stem/progenitor cell markers in HBx-transgenic mice treated with 3,5-diethoxycarbonyl-1,4-dihydrocollidine (DDC) [70]. These results were confirmed by the increase of IL-6/STAT3 and Wnt/ $\beta$-catenin signaling activities in HBx- transgenic mice [70].

It has been reported that HBx interacts with heat shock proteins (HSPs) in mitochondria [71,72]. HSP60 is matured in the mitochondrial matrix after cleavage [73]. Tanaka et al. demonstrated that HBx interacted with endogenous HSP60 in transfected Huh7 cells and enhanced HBx-mediated apoptosis [71]. Although HSP70 is mainly localized at the endoplasmic reticulum, mitochondrial HSP70 plays a vital role for mitochondrial protein folding [74]. HBx binds with the mitochondrial HSP70 and forms a complex with endogenous HSP60 and HSP70 in transfected COS7 cells to fulfill its function [72]. Parvulin 17 (Par17) is targeted to mitochondrial matrix but parvulin 14 (Par14) localizes in the cytoplasm, nucleus, and mitochondria as well $[75,76]$. Par14 and Par 17, which play roles in protein folding, chromatin remodeling, cell cycle progression and so on, directly interact with $\mathrm{HBx}$ and promote $\mathrm{HBx}$ translocation to the nucleus and mitochondrial fractions, and upregulate HBV DNA replication [77]. The Par14/17-HBx interaction and colocalization have been confirmed by cell fractionation assay followed by IP and by IFA in transfected HEK293T cells. However, the authors hypothesized that the interaction between Par14/17 and HBx forms a complex with cccDNA (cccDNA-Par14/17-HBx complex) and this complex upregulates the HBV RNA transcription [77].

Mitochondrial antiviral signaling protein (MAVS) localizes at mitochondria by its C-terminal transmembrane anchor and mitochondria-associated membranes (MAMs) [78,79]. In addition, MAVS directly interacts with a translocase of the outer mitochondrial membrane 70 (TOM70) during viral infections, and TOM70 associates with HSP90 [80,81]. Several reports have suggested that HBx likely interacts with MAVS and attenuates antiviral immune responses $[5,82,83]$. Kumar et al. confirmed the interaction of HBx with MAVS in HBx-transgenic mice and transfected HepG2 cells [84]. Wei et al. 
also demonstrated that HBx interacted with endogenous MAVS in HEK293T cells, which were transfected with Myc-tagged HBx [82]. Parkin is an E3 ligase that plays an important role in protein ubiquitination [85]. HBx stimulates parkin to interact with MAVS through recruitment of the linear ubiquitin assembly complex (LUBAC) for disruption of the MAVS signalosome and for attenuation of IRF3 activation [83]. HBx also bind with parkin in Huh7 cells cotransfected with Flag- HBx and mCherry-Parkin [7]. HBx promotes the degradation of MAVS through ubiquitination and blocks MAVS-mediated IFN- $\beta$ induction [82]. HBx-mediated MAVS degradation strongly correlated with the results from clinical HCC samples from HBV patients and HBx transgenic mice [82]. Thus virus-induced RIG-I-MAVS signaling is inhibited by HBx, which leads to attenuation of antiviral immune responses of the innate immune system $[5,82]$. However, a recent study has been conducted by collecting liver tissue samples from chronic HBV patients and demonstrated that HBV does not interfere with the innate immune response [86].

Therefore, considering all of the above results, it might be stated that $\mathrm{HBx}$ has a role for development of HBV-mediated HCC by modulating mROS, $\triangle \psi \mathrm{m}$, and mtDNA through the activation of several transcription factors. As discussed above, several reports also demonstrated that HBx may play a role in mitochondria-mediated cellular apoptosis and attenuation of innate immune response. During these processes, at least a fraction of HBx may localize at mitochondria, and directly or indirectly interacts with many kinds of mitochondrial proteins, and exerts effects on the morphological and functional changes of mitochondria, thereby regulating various kinds of cellular responses which are advantageous to HBV replication (Figure 2). However, a few reports also demonstrated that HBx localized into the nucleus either in Huh7 and HepG2 cells transfected with HBx-expressing plasmids and HBV-infected PHH $[87,88]$. Kornyeyev et al. showed that HBx was mainly detected in the nucleus in HBV-infected PHH cells. In contrast, the HBx mutant lost the DDB1- binding activity; which was detected in both the cytoplasm and nucleus, suggesting that the nuclear localization of HBx depends on the interaction of HBx with DDB1. Although authors explained that the cytoplasmic localization of HBx may occur as results of saturation of the HBx-DDB1 interaction, because the cytoplasmic HBx was detected only in the highly expressing cells [87].

\subsection{Polymerase}

HBV polymerase (pol) is a multifunctional reverse transcriptase protein, and its ORF overlaps with the three other ORFs, S, X, and C. It has four domains: a terminal protein (TP), spacer, reverse transcriptase (RT), and RNase $\mathrm{H}$ domain. Pol plays essential roles in viral $\varepsilon$ RNA binding to package pgRNA into nucleocapsids, and initiates reverse transcription [89,90]. During HBV replication, pol also interacts with many cellular proteins, including mitochondrial ones [20,91-93].

A recent study reported that pol has a mitochondrial targeting signal (MTS) and localizes at the mitochondria in HBV-replicating Huh7 cells transfected with HBV genome under the control of CMV immediate early promoter, but neither core nor pgRNA localizes there during viral DNA replication [20]. Many reports have indicated that pol inhibits innate immune responses by preventing the upregulation of interferon regulatory factor 3 (IRF-3) [92,94]. Liu et al. clearly demonstrated the pol- mediated downregulation of IFN- $\beta$ through direct interaction with stimulator of interferon genes (STING) in Huh7 cells transfected with plasmid pHBV1.3 or pCMV-HBV [95]. RT domain of pol also drastically reduces the K63-linked polyubiquitination of STING, which is necessary for the activation of IFN induction pathway $[95,96]$. It has been reported that STING associates with MAMs [5]. Therefore, Unchwaniwala et al. assumed that pol might interact with STING at mitochondria, although they did not discuss the involvement of mitochondria in pol-mediated immune responses in their study (Figure 2) [20]. Again it should be mentioned here, Suslov et al. demonstrated that HBV does not interfere with the innate immune response in chronic HBV-infected patients [86]. 


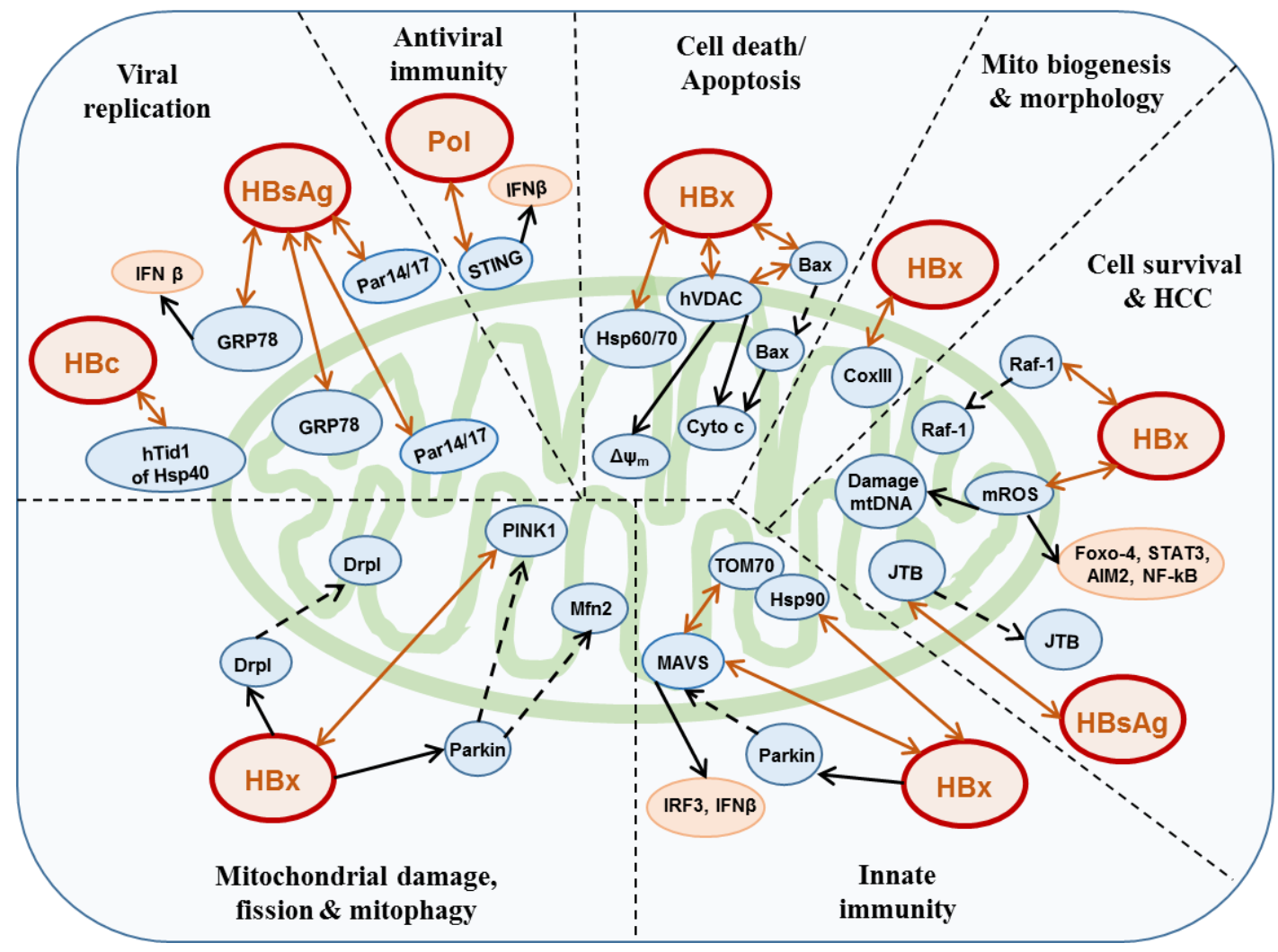

Figure 2. Interactions between HBV proteins and mitochondrial proteins. HBx interacts with different mitochondrial proteins and/or translocates several cytosolic proteins into mitochondria, which affects mitochondrial fission, morphology, and biogenesis and leads to mitophagy/dysfunction. Innate immunity is lost due to decreased activities of IRF3 and IFN- $\beta$ through MAVS/parkin/HBx interaction. Cell death/apoptosis may occur due to loss of $\Delta \psi \mathrm{m}$ and release of cytochrome c induced by HBx. Increase in mROS due to HBx causes mtDNA destruction and activation of oncogenic transcription factors, which might lead to HCC development. Pol interacts with STING and reduces the antiviral immunity through suppression of IFN- $\beta$. HBsAg interacts with and degrades GRP78 and up-regulates IFN- $\beta$ to suppress HBV replication. Viral replication is also suppressed by degradation of HBc and HBx through interaction between HBc and hTid1. HBx translocates Raf1 into mitochondria. HBsAg binds with JTB and reduces the mitochondrial localization of JTB. Double arrows indicate interactions and dashed arrows indicate translocations.

\section{3. $H B s A g$}

The HBV nucleocapsid is surrounded by three surface (envelope) proteins encoded by an ORF preS-S sharing a common S ORF. The large surface protein (LHBsAg, LS) consists of preS1, preS2, and S ORF, and the middle one (MHBsAg, MS) consists of preS2 and S, whereas the smallest one (SHBsAg, SS) contains only S ORF [97]. Subviral particles consisting of MS and SS are produced in greater excess compared to mature viral particles, and all three envelope proteins are required for efficient infectious HBV (Dane particles) formation [11], even though MS is not necessary. HBV attaches to cells by the preS1 regions of the LS, whereas SS is an important determinant for diagnosis [12].

The ubiquitous molecular chaperone GRP78 generally localizes at ER, but a part of GRP78 is also present in mitochondria, especially in the intermembrane space, inner membrane, and matrix under the unfolded protein response (UPR) [98]. ER stress is activated by HBV infection through the ERassociated degradation (ERAD) pathway in persistently replicating HepG2 2.2.15 cells, and reduces the production of envelope proteins [99]. GRP78 is up-regulated in HepAD38 cells, a persistently HBV genome-integrated cell line under the control of a tet operator/CMV promoter and inhibits viral replication through the IFN- $\beta$-mediated pathway [100]. However, GRP78 expression was lower in liver 
tissues of post lamivudine treated clinical patients compared with pretreated cases though it showed cytoplasmic and perinuclear staining pattern [100]. Moreover, Cho et al. demonstrated that GRP78 binds with preS1 of LS in HepG2 cells transfected with a replication competent plasmid pHBV5.2 under the control of autologous regulatory elements, although exact importance of GRP78 in HBV replication has not been clarified [101]. Heat shock protein family A (HSP70) family member 9 (HSPA9), also known as GRP75, is primarily localized in mitochondria but also found at lower levels in the ER [102]. GRP75 is involved in cell proliferation by interacting with p53 [103]. The preS1 region of LS physically binds with the GRP75 in co-transfected COS7 cells, where it is expected to regulate proper folding of HBV envelope proteins [104]. Though, HBV envelope proteins are assembled with naked capsids on the ER-Golgi and/or multivesicular body (MVB) [105-107] none of the above studies showed colocalization of HBsAg and GRP75/78 specifically in mitochondria.

SS binds with enoyl-coA hydratase short chain 1 (ECHS1), which is located in the mitochondrial matrix, acts on the fatty acid beta-oxidation pathway, and reduces the ECHS1 expression in hepatoma cells [108]. A study reported that SS interacted with ECHS1 in the cytoplasm of co-transfected 293FT cells, and that co-existence of ECHS1 and SS induced apoptosis by decreasing $\Delta \psi \mathrm{m}$ and upregulating pro-apoptotic proteins (Bad, Bid, Bim, etc.) in HepG2 cells stably expressing HBs [109]. Jumping translocation breakpoint (JTB) protein is overexpressed in HCC, and is thought to play an important role in oncogenesis in the liver $[110,111]$. SS is reported to bind with JTB in transfected HepG2 cells and reduce the mitochondrial localization of JTB, and to inhibit phosphorylation of p65, a subunit of the NF-кB complex, implying that SS might have a role in HCC progression (Figure 2) [110].

These reports suggest that some SS is localized in the mitochondria, where it associates with a few mitochondrial proteins and affects their function.

\subsection{Core}

HBV core $(\mathrm{HBc})$ is a small protein, consisting of 183 amino acids produced by ORF C, which is self-assembled to form viral capsids [112-114]. The hTid1, a family protein of HSP40, predominantly localizes in mitochondria and is involved in apoptosis [115-117]. The hTid1 interacts with HBc and reduces viral replication by degradation of $\mathrm{HBc}$ and $\mathrm{HBx}$ proteins (Figure 2) [118]. The authors confirmed the hTid1-HBc interaction in Huh7 cells co-transfected with pcDNA6/V5-HisA (hTid1) and $\mathrm{pHBcHA}(\mathrm{HBc})$ and investigated these effects in HepG2 cells transfected with replication competent plasmid pHBV1.3 under the control of CMV promoter [118].

\section{Conclusions and Perspectives}

According to most of the studies discussed above, at least some fraction of HBx may localize and/or associate with the mitochondria and associated proteins to disturb mitochondrial dynamics/signaling and could play a momentous role in HBV-mediated HCC formation. Many host proteins/factors such as transcriptional, anti-apoptotic, pro-apoptotic, and innate immune-related proteins are thought to be involved during HBx-mitochondria mediated pathogenesis. There is a possibility that another functional protein, pol, could benefit from mitochondria by suppressing STING-mediated antiviral signaling. As for HBsAg, it is ubiquitous in and around mitochondria and could interact with some factors therein. However, most of these studies regarding HBV and mitochondria have been conducted in an overexpression system, and a few reports also showed that HBx predominantly localized into nucleus even in infection condition. Therefore, such phenomena/mechanisms should be verified in infection systems and also in HBV-infected patients.

In conclusion, $\mathrm{HBV}$ has been suggested to exert substantial effects on mitochondria to change mitochondrial dynamics/signaling, leading to HCC development. Further investigations of the relationships between HBV and mitochondria are needed to improve our understanding of mitochondrial involvement in the HBV life cycle. Such research could open a door to novel therapeutic strategies directed at mitochondria. 
Author Contributions: M.G.H. searched and reviewed the literature, and wrote the manuscript. E.O. and K.U. revised and edited the manuscript. M.G.H., S.A., E.O., and K.U. revised the manuscript. All authors read and approved the final version of the manuscript.

Conflicts of Interest: The authors declare no conflict of interest.

\section{References}

1. Endo, T.; Yamano, K. Multiple pathways for mitochondrial protein traffic. Boil. Chem. 2009, 390, 723-730. [CrossRef]

2. Wang, C.; Youle, R.J. The role of mitochondria in apoptosis*. Annu. Rev. Genet. 2009, 43, 95-118. [CrossRef] [PubMed]

3. Hayashi, T.; Rizzuto, R.; Hajnoczky, G.; Su, T.P. MAM: More than just a housekeeper. Trends Cell Biol. 2009, 19, 81-88. [CrossRef] [PubMed]

4. Degli Esposti, D.; Hamelin, J.; Bosselut, N.; Saffroy, R.; Sebagh, M.; Pommier, A.; Martel, C.; Lemoine, A. Mitochondrial Roles and Cytoprotection in Chronic Liver Injury. Biochem. Res. Int. 2012, 2012, 1-16. [CrossRef]

5. West, A.P.; Shadel, G.S.; Ghosh, S. Mitochondria in innate immune responses. Nat. Rev. Immunol. 2011, 11, 389-402. [CrossRef] [PubMed]

6. Khan, M.; Syed, G.H.; Kim, S.-J.; Siddiqui, A. Mitochondrial dynamics and viral infections: A close nexus. Biochim. Biophys. Acta (BBA) Bioenerg. 2015, 1853, 2822-2833. [CrossRef]

7. Kim, S.-J.; Khan, M.; Quan, J.; Till, A.; Subramani, S.; Siddiqui, A. Hepatitis B Virus Disrupts Mitochondrial Dynamics: Induces Fission and Mitophagy to Attenuate Apoptosis. PLoS Pathog. 2013, 9, e1003722. [CrossRef]

8. Anand, S.K.; Tikoo, S.K. Viruses as Modulators of Mitochondrial Functions. Adv. Virol. 2013, $2013,1-17$. [CrossRef]

9. El-Serag, H.B. Epidemiology of viral hepatitis and hepatocellular carcinoma. Gastroenterology 2012, 142, 1264-1273. [CrossRef] [PubMed]

10. Hossain, M.G.; Ueda, K. A meta-analysis on genetic variability of RT/HBsAg overlapping region of hepatitis B virus (HBV) isolates of Bangladesh. Infect. Agents Cancer 2019, 14, 1-8. [CrossRef] [PubMed]

11. Ueda, K.; Tsurimoto, T.; Matsubara, K. Three envelope proteins of hepatitis B virus: Large S, middle S, and major $S$ proteins needed for the formation of Dane particles. J. Virol. 1991, 65, 3521-3529. [CrossRef] [PubMed]

12. Hossain, M.G.; Ueda, K. Investigation of a Novel Hepatitis B Virus Surface Antigen (HBsAg) Escape Mutant Affecting Immunogenicity. PLoS ONE 2017, 12, e0167871. [CrossRef]

13. Delius, H.; Gough, N.M.; Cameron, C.H.; Murray, K. Structure of the hepatitis B virus genome. J. Virol. 1983, 47,337-343. [CrossRef] [PubMed]

14. Sprengel, R.; Kühn, C.; Will, H.; Schaller, H. Comparative sequence analysis of duck and human hepatitis B virus genomes. J. Med Virol. 1985, 15, 323-333. [CrossRef] [PubMed]

15. Hossain, M.G.; Mahmud, M.; Nazir, K.H.M.N.H.; Ueda, K. PreS1 Mutations Alter the Large HBsAg Antigenicity of a Hepatitis B Virus Strain Isolated in Bangladesh. Int. J. Mol. Sci. 2020, 21, 546. [CrossRef] [PubMed]

16. Yan, H.; Zhong, G.; Xu, G.; He, W.; Jing, Z.; Gao, Z.; Huang, Y.; Qi, Y.; Peng, B.; Wang, H.; et al. Sodium taurocholate cotransporting polypeptide is a functional receptor for human hepatitis $\mathrm{B}$ and $\mathrm{D}$ virus. eLife 2012, 1, e00049. [CrossRef] [PubMed]

17. Beck, J.; Nassal, M. Hepatitis B virus replication. World J. Gastroenterol. 2007, 13, 48-64. [CrossRef]

18. Grimm, D.; Thimme, R.; Blum, H.E. HBV life cycle and novel drug targets. Hepatol. Int. 2011, 5, 644-653. [CrossRef]

19. Prange, R. Host factors involved in hepatitis B virus maturation, assembly, and egress. Med. Microbiol. Immunol. 2012, 201, 449-461. [CrossRef]

20. Unchwaniwala, N.; Sherer, N.M.; Loeb, D.D. Hepatitis B Virus Polymerase Localizes to the Mitochondria, and Its Terminal Protein Domain Contains the Mitochondrial Targeting Signal. J. Virol. 2016, 90, 8705-8719. [CrossRef] 
21. Shirakata, Y.; Koike, K. Hepatitis B Virus X Protein Induces Cell Death by Causing Loss of Mitochondrial Membrane Potential. J. Boil. Chem. 2003, 278, 22071-22078. [CrossRef] [PubMed]

22. Rahmani, Z.; Huh, K.-W.; Lasher, R.; Siddiqui, A. Hepatitis B Virus X Protein Colocalizes to Mitochondria with a Human Voltage-Dependent Anion Channel, HVDAC3, and Alters Its Transmembrane Potential. J. Virol. 2000, 74, 2840-2846. [CrossRef] [PubMed]

23. Henkler, F.; King, I.A.; Hoare, J.; McGarvey, M.J.; Waseem, N.; Koshy, R.; Goldin, R.D. Intracellular localization of the hepatitis B virus HBx protein. J. Gen. Virol. 2001, 82, 871-882. [CrossRef] [PubMed]

24. Gehring, A.; Bertoletti, A.; Tavis, J.E. Host Factor-Targeted Hepatitis B Virus Therapies. Intervirology 2014, 57, 158-162. [CrossRef] [PubMed]

25. Bouchard, M.J.; Navas-Martin, S. Hepatitis B and C virus hepatocarcinogenesis: Lessons learned and future challenges. Cancer Lett. 2011, 305, 123-143. [CrossRef] [PubMed]

26. Bouchard, M.J.; Schneider, R.J. The Enigmatic X Gene of Hepatitis B Virus. J. Virol. 2004, 78, 12725-12734. [CrossRef]

27. Rawat, S.; Clippinger, A.J.; Bouchard, M.J. Modulation of Apoptotic Signaling by the Hepatitis B Virus X Protein. Viruses 2012, 4, 2945-2972. [CrossRef]

28. Casciano, J.C.; Bouchard, M.J. Hepatitis B virus X protein modulates cytosolic Ca2+ signaling in primary human hepatocytes. Virus Res. 2018, 246, 23-27. [CrossRef]

29. Takada, S.; Shirakata, Y.; Kaneniwa, N.; Koike, K. Association of hepatitis B virus X protein with mitochondria causes mitochondrial aggregation at the nuclear periphery, leading to cell death. Oncogene 1999, 18, 6965-6973. [CrossRef]

30. Huh, K.-W.; Siddiqui, A. Characterization of the mitochondrial association of hepatitis B virus X protein, HBx. Mitochondrion 2002, 1, 349-359. [CrossRef]

31. Adachi, M.; Higuchi, H.; Miura, S.; Azuma, T.; Inokuchi, S.; Saito, H.; Kato, S.; Ishii, H. Bax interacts with the voltage-dependent anion channel and mediates ethanol-induced apoptosis in rat hepatocytes. Am. J. Physiol. Liver Physiol. 2004, 287, G695-G705. [CrossRef]

32. Clippinger, A.J.; Bouchard, M.J. Hepatitis B Virus HBx Protein Localizes to Mitochondria in Primary Rat Hepatocytes and Modulates Mitochondrial Membrane Potential. J. Virol. 2008, 82, 6798-6811. [CrossRef] [PubMed]

33. Hardwick, J.M.; Soane, L. Multiple Functions of BCL-2 Family Proteins. Cold Spring Harb. Perspect. Boil. 2013, 5, a008722. [CrossRef] [PubMed]

34. Li, S.K.; Ho, S.F.; Tsui, K.W.; Fung, K.P.; Waye, M.M. Identification of functionally important amino acid residues in the mitochondria targeting sequence of Hepatitis B virus X protein. Virology 2008, 381, 81-88. [CrossRef] [PubMed]

35. Waris, G.; Huh, K.-W.; Siddiqui, A. Mitochondrially Associated Hepatitis B Virus X Protein Constitutively Activates Transcription Factors STAT-3 and NF-kB via Oxidative Stress. Mol. Cell. Boil. 2001, 21, 7721-7730. [CrossRef]

36. Jung, S.-Y.; Kim, Y.-J. C-terminal region of HBx is crucial for mitochondrial DNA damage. Cancer Lett. 2013, 331, 76-83. [CrossRef]

37. He, P.; Zhang, D.; Li, H.; Yang, X.; Li, D.; Zhai, Y.; Ma, L.; Feng, G. Hepatitis B virus X protein modulates apoptosis in human renal proximal tubular epithelial cells by activating the JAK2/STAT3 signaling pathway. Int. J. Mol. Med. 2013, 31, 1017-1029. [CrossRef]

38. Li, L.; Hann, H.-W.; Wan, S.; Hann, R.S.; Wang, C.; Lai, Y.; Ye, X.; Evans, A.; Myers, R.E.; Ye, Z.; et al. Cell-free circulating mitochondrial DNA content and risk of hepatocellular carcinoma in patients with chronic HBV infection. Sci. Rep. 2016, 6, 23992. [CrossRef]

39. Chen, T.; Xun, Z.; Lin, J.; Fu, Y.; Wu, W.; Fu, X.; Hu, Y.; Zeng, Y.; Ou, Q. Association between mitochondrial DNA content and baseline serum levels of HBsAg in chronic hepatitis B infection. J. Med. Virol. 2017, 89, 1958-1962. [CrossRef]

40. Zhao, S.; Yang, Y.; Liu, J.; Liu, H.; Ge, N.; Yang, H.; Zhang, H.; Xing, J. Association of mitochondrial DNA content in peripheral blood leukocyte with hepatitis B virus-related hepatocellular carcinoma in a Chinese Han population. Cancer Sci. 2011, 102, 1553-1558. [CrossRef]

41. Wang, C.; Hann, H.-W.; Hann, R.S.; Wan, S.; Myers, R.E.; Ye, Z.; Xing, J.; Yang, H. Circulating Mitochondrial DNA Content Associated with the Risk of Liver Cirrhosis: A Nested Case-Control Study. Dig. Dis. Sci. 2015, 60, 1707-1715. [CrossRef] [PubMed] 
42. Yamada, S.; Nomoto, S.; Fujii, T.; Kaneko, T.; Takeda, S.; Inoue, S.; Kanazumi, N.; Nakao, A. Correlation between copy number of mitochondrial DNA and clinico-pathologic parameters of hepatocellular carcinoma. Eur. J. Surg. Oncol. (EJSO) 2006, 32, 303-307. [CrossRef] [PubMed]

43. Fisicaro, P.; Barili, V.; Montanini, B.; Acerbi, G.; Ferracin, M.; Guerrieri, F.; Salerno, D.; Boni, C.; Massari, M.; Cavallo, M.C.; et al. Targeting mitochondrial dysfunction can restore antiviral activity of exhausted HBV-specific CD8 T cells in chronic hepatitis B. Nat. Med. 2017, 23, 327-336. [CrossRef] [PubMed]

44. Lee, Y.I.; Hwang, J.M.; Im, J.H.; Lee, Y.I.; Kim, N.S.; Kim, D.G.; Yu, D.Y.; Moon, H.B.; Park, S.K. Human Hepatitis B Virus-X Protein Alters Mitochondrial Function and Physiology in Human Liver Cells. J. Boil. Chem. 2004, 279, 15460-15471. [CrossRef] [PubMed]

45. Chen, J.; Siddiqui, A. Hepatitis B Virus X Protein Stimulates the Mitochondrial Translocation of Raf-1 via Oxidative Stress. J. Virol. 2007, 81, 6757-6760. [CrossRef] [PubMed]

46. Zheng, B.-Y.; Fang, X.-F.; Zou, L.-Y.; Huang, Y.-H.; Chen, Z.-X.; Li, D.; Zhou, L.-Y.; Chen, H.; Wang, X.-Z. The co-localization of HBx and COXIII upregulates COX-2 promoting HepG2 cell growth. Int. J. Oncol. 2014, 45, 1143-1150. [CrossRef] [PubMed]

47. Wang, X.Z.; Tao, Q.M.; Chen, Z.X.; Li, D.; Lin, N. A novel hepatitis B virus X?interactive protein: Cytochrome C oxidase III. J. Gastroenterol. Hepatol. 2006, 21, 711-715. [CrossRef]

48. Li, D.; Wang, X.-Z.; Yu, J.-P.; Chen, Z.-X.; Huang, Y.-H.; Tao, Q.-M. Cytochrome C oxidase III interacts with hepatitis B virus X protein in vivo by yeast two-hybrid system. World J. Gastroenterol. 2004, 10, 2805-2808. [CrossRef]

49. Zou, L.-Y.; Zheng, B.-Y.; Fang, X.-F.; Li, D.; Huang, Y.-H.; Chen, Z.-X.; Zhou, L.-Y.; Wang, X.-Z. HBx co-localizes with COXIII in HL-7702 cells to upregulate mitochondrial function and ROS generation. Oncol. Rep. 2015, 33, 2461-2467. [CrossRef]

50. Yoo, Y.-S.; Park, Y.-J.; Lee, H.-S.; Oanh, N.T.K.; Cho, M.-Y.; Heo, J.; Lee, E.-S.; Cho, H.; Park, Y.-Y. Mitochondria ubiquitin ligase, MARCH5 resolves hepatitis B virus $\mathrm{X}$ protein aggregates in the liver pathogenesis. Cell Death Dis. 2019, 10, 938. [CrossRef]

51. Yonashiro, R.; Ishido, S.; Kyo, S.; Fukuda, T.; Goto, E.; Matsuki, Y.; Ohmura-Hoshino, M.; Sada, K.; Hotta, H.; Yamamura, H.; et al. A novel mitochondrial ubiquitin ligase plays a critical role in mitochondrial dynamics. EMBO J. 2006, 25, 3618-3626. [CrossRef] [PubMed]

52. Park, Y.-Y.; Nguyen, O.T.K.; Kang, H.; Cho, H. MARCH5-mediated quality control on acetylated Mfn1 facilitates mitochondrial homeostasis and cell survival. Cell Death Dis. 2014, 5, e1172. [CrossRef] [PubMed]

53. Nagashima, S.; Tokuyama, T.; Yonashiro, R.; Inatome, R.; Yanagi, S. Roles of mitochondrial ubiquitin ligase MITOL/MARCH5 in mitochondrial dynamics and diseases. J. Biochem. 2014, 155, 273-279. [CrossRef] [PubMed]

54. Karbowski, M.; Neutzner, A.; Youle, R.J. The mitochondrial E3 ubiquitin ligase MARCH5 is required for Drp1 dependent mitochondrial division. J. Cell Boil. 2007, 178, 71-84. [CrossRef] [PubMed]

55. Liu, B.; Qu, L.; Yan, S. Cyclooxygenase-2 promotes tumor growth and suppresses tumor immunity. Cancer Cell Int. 2015, 15, 106. [CrossRef]

56. Park, M.H.; Hong, J.T. Roles of NF-кB in Cancer and Inflammatory Diseases and Their Therapeutic Approaches. Cells 2016, 5, 15. [CrossRef]

57. Man, S.M.; Zhu, Q.; Zhu, L.; Liu, Z.; Karki, R.; Malik, A.; Sharma, D.; Li, L.; Malireddi, R.S.; Gurung, P.; et al. Critical Role for the DNA Sensor AIM2 in Stem Cell Proliferation and Cancer. Cell 2015, 162, 45-58. [CrossRef] [PubMed]

58. Chen, I.-F.; Ou-Yang, F.; Hung, J.-Y.; Liu, J.-C.; Wang, H.; Wang, S.-C.; Hou, M.-F.; Hortobagyi, G.N.; Hung, M.-C. AIM2 suppresses human breast cancer cell proliferation in vitro and mammary tumor growth in a mouse model. Mol. Cancer Ther. 2006, 5, 1-7. [CrossRef]

59. Chen, S.-L.; Liu, L.-L.; Lu, S.-X.; Luo, R.-Z.; Wang, C.-H.; Wang, H.; Cai, S.-H.; Yang, X.; Xie, D.; Zhang, C.Z.; et al. HBx-mediated decrease of AIM2 contributes to hepatocellular carcinoma metastasis. Mol. Oncol. 2017, 11, 1225-1240. [CrossRef]

60. McClain, S.L.; Clippinger, A.J.; Lizzano, R.; Bouchard, M.J. Hepatitis B Virus Replication Is Associated with an HBx-Dependent Mitochondrion-Regulated Increase in Cytosolic Calcium Levels. J. Virol. 2007, 81, 12061-12065. [CrossRef] [PubMed]

61. Scaglioni, P.P.; Melegari, M.; Wands, J.R. Posttranscriptional regulation of hepatitis B virus replication by the precore protein. J. Virol. 1997, 71, 345-353. [CrossRef] [PubMed] 
62. Kim, H.J.; Kim, S.Y.; Kim, J.; Lee, H.; Choi, M.; Kim, J.K.; Ahn, J.K. Hepatitis B virus X protein induces apoptosis by enhancing translocation of Bax to mitochondria. IUBMB Life 2008, 60, 473-480. [CrossRef] [PubMed]

63. Gao, W.Y.; Li, D.; Cai, D.E.; Huang, X.Y.; Zheng, B.Y.; Huang, Y.H.; Chen, Z.X.; Wang, X.Z. Hepatitis B virus $X$ protein sensitizes HL-7702 cells to oxidative stress-induced apoptosis through modulation of the mitochondrial permeability transition pore. Oncol. Rep. 2017, 37, 48-56. [CrossRef] [PubMed]

64. Dudek, J. Role of Cardiolipin in Mitochondrial Signaling Pathways. Front. Cell Dev. Boil. 2017, 5, 90. [CrossRef]

65. You, D.-G.; Cho, Y.Y.; Lee, H.-R.; Lee, J.-H.; Yu, S.J.; Yoon, J.-H.; Yoo, Y.D.; Kim, Y.J.; Lee, G.Y. Hepatitis B virus $\mathrm{X}$ protein induces size-selective membrane permeabilization through interaction with cardiolipin. Biochim. Biophys. Acta (BBA) Biomembr. 2019, 1861, 729-737. [CrossRef]

66. Narendra, D.P.; Jin, S.M.; Tanaka, A.; Suen, D.-F.; Gautier, C.A.; Shen, J.; Cookson, M.R.; Youle, R.J. PINK1 is selectively stabilized on impaired mitochondria to activate Parkin. PLoS Boil. 2010, 8, e1000298. [CrossRef]

67. Huang, X.-Y.; Li, D.; Chen, Z.-X.; Huang, Y.-H.; Gao, W.-Y.; Zheng, B.-Y.; Wang, X.-Z. Hepatitis B Virus X protein elevates Parkin-mediated mitophagy through Lon Peptidase in starvation. Exp. Cell Res. 2018, 368, 75-83. [CrossRef]

68. Ogura, N.; Ogawa, K.; Watashi, K.; Ito, T.; Wakita, T. Novel stable HBV producing cell line systems for expression and screening antiviral inhibitor of hepatitis B virus in human hepatoma cell line. Biochem. Biophys. Res. Commun. 2018, 498, 64-71. [CrossRef]

69. Chi, H.-C.; Chen, S.-L.; Lin, S.-L.; Tsai, C.-Y.; Chuang, W.-Y.; Lin, Y.-H.; Huang, Y.-H.; Tsai, M.-M.; Yeh, C.-T.; Lin, K.-H. Thyroid hormone protects hepatocytes from HBx-induced carcinogenesis by enhancing mitochondrial turnover. Oncogene 2017, 36, 5274-5284. [CrossRef]

70. Wang, C.; Yang, W.; Yan, H.X.; Luo, T.; Zhang, J.; Tang, L.; Wu, F.Q.; Zhang, H.L.; Yu, L.X.; Zheng, L.Y.; et al. Hepatitis B virus $\mathrm{X}(\mathrm{HBx})$ induces tumorigenicity of hepatic progenitor cells in 3,5-diethoxycarbonyl-1,4-dihydrocollidine-treated HBx transgenic mice. Hepatology 2012, 55, 108-120. [CrossRef]

71. Tanaka, Y.; Kanai, F.; Kawakami, T.; Tateishi, K.; Ijichi, H.; Kawabe, T.; Arakawa, Y.; Kawakami, T.; Nishimura, T.; Shirakata, Y.; et al. Interaction of the hepatitis B virus X protein (HBx) with heat shock protein 60 enhances HBx-mediated apoptosis. Biochem. Biophys. Res. Commun. 2004, 318, 461-469. [CrossRef] [PubMed]

72. Zhang, S.M.; Sun, D.C.; Lou, S.; Bo, X.C.; Lu, Z.; Qian, X.H.; Wang, S.Q. HBx protein of hepatitis B virus (HBV) can form complex with mitochondrial HSP60 and HSP70. Arch. Virol. 2005, 150, 1579-1590. [CrossRef] [PubMed]

73. Singh, B.; Patel, H.V.; Ridley, R.G.; Freeman, K.B.; Gupta, R.S. Mitochondrial import of the human chaperonin (HSP60) protein. Biochem. Biophys. Res. Commun. 1990, 169, 391-396. [CrossRef]

74. Azem, A.; Oppliger, W.; Lustig, A.; Jenö, P.; Feifel, B.; Schatz, G.; Horst, M. The mitochondrial hsp70 chaperone system. Effect of adenine nucleotides, peptide substrate, and mGrpE on the oligomeric state of mhsp70. J. Boil. Chem. 1997, 272, 20901-20906. [CrossRef]

75. Mueller, J.W.; Bayer, P. Small Family with Key Contacts: Par14 and Par17 Parvulin Proteins, Relatives of Pin1, Now Emerge in Biomedical Research. Perspect. Med. Chem. 2008, 2, 11-20. [CrossRef]

76. Rulten, S.; Thorpe, J.; Kay, J. Identification of Eukaryotic Parvulin Homologues: A New Subfamily of Peptidylprolyl cis-trans Isomerases. Biochem. Biophys. Res. Commun. 1999, 259, 557-562. [CrossRef]

77. Saeed, U.; Kim, J.; Piracha, Z.Z.; Kwon, H.; Jung, J.; Chwae, Y.-J.; Park, S.; Shin, H.-J.; Kim, K. Parvulin 14 and Parvulin 17 Bind to HBx and cccDNA and Upregulate Hepatitis B Virus Replication from cccDNA to Virion in an HBx-Dependent Manner. J. Virol. 2019, 93, e01840-18. [CrossRef]

78. Vazquez, C.; Horner, S.M. MAVS Coordination of Antiviral Innate Immunity. J. Virol. 2015, 89, 6974-6977. [CrossRef]

79. Seth, R.B.; Sun, L.; Ea, C.K.; Chen, Z.J. Identification and characterization of MAVS, a mitochondrial antiviral signaling protein that activates NF-kappaB and IRF 3. Cell 2005, 122, 669-682. [CrossRef]

80. Liu, X.-Y.; Wei, B.; Shi, H.-X.; Shan, Y.-F.; Wang, C. Tom70 mediates activation of interferon regulatory factor 3 on mitochondria. Cell Res. 2010, 20, 994-1011. [CrossRef]

81. Fan, A.C.Y.; Bhangoo, M.K.; Young, J.C. Hsp90 Functions in the Targeting and Outer Membrane Translocation Steps of Tom70-mediated Mitochondrial Import. J. Boil. Chem. 2006, 281, 33313-33324. [CrossRef] [PubMed] 
82. Wei, C.; Ni, C.; Song, T.; Liu, Y.; Yang, X.; Zheng, Z.; Jia, Y.; Yuan, Y.; Guan, K.; Xu, Y.; et al. The Hepatitis B Virus $X$ Protein Disrupts Innate Immunity by Downregulating Mitochondrial Antiviral Signaling Protein. J. Immunol. 2010, 185, 1158-1168. [CrossRef] [PubMed]

83. Khan, M.; Syed, G.H.; Kim, S.-J.; Siddiqui, A. Hepatitis B Virus-Induced Parkin-Dependent Recruitment of Linear Ubiquitin Assembly Complex (LUBAC) to Mitochondria and Attenuation of Innate Immunity. PLoS Pathog. 2016, 12, e1005693. [CrossRef] [PubMed]

84. Kumar, M.; Jung, S.Y.; Hodgson, A.J.; Madden, C.R.; Qin, J.; Slagle, B.L. Hepatitis B Virus Regulatory HBx Protein Binds to Adaptor Protein IPS-1 and Inhibits the Activation of Beta Interferon. J. Virol. 2011, 85, 987. [CrossRef]

85. Chung, K.K.K.; Thomas, B.; Li, X.; Pletnikova, O.; Troncoso, J.C.; Marsh, L.; Dawson, V.L.; Dawson, T.M. Nitrosylation of Parkin Regulates Ubiquitination and Compromises Parkin's Protective Function. Science 2004, 304, 1328. [CrossRef]

86. Suslov, A.; Boldanova, T.; Wang, X.; Wieland, S.; Heim, M.H. Hepatitis B Virus Does Not Interfere With Innate Immune Responses in the Human Liver. Gastroenterology 2018, 154, 1778-1790. [CrossRef]

87. Kornyeyev, D.; Ramakrishnan, D.; Voitenleitner, C.; Livingston, C.M.; Xing, W.; Hung, M.; Kwon, H.J.; Fletcher, S.P.; Beran, R.K. Spatiotemporal Analysis of Hepatitis B Virus X Protein in Primary Human Hepatocytes. J. Virol. 2019, 93, e00248-19. [CrossRef]

88. Keasler, V.V.; Hodgson, A.J.; Madden, C.R.; Slagle, B.L. Hepatitis B virus HBx protein localized to the nucleus restores HBx-deficient virus replication in HepG2 cells and in vivo in hydrodynamically-injected mice. Virology 2009, 390, 122-129. [CrossRef]

89. Harrison, A.; Lemey, P.; Hurles, M.; Moyes, C.; Horn, S.; Pryor, J.; Malani, J.; Supuri, M.; Masta, A.; Teriboriki, B.; et al. Genomic Analysis of Hepatitis B Virus Reveals Antigen State and Genotype as Sources of Evolutionary Rate Variation. Viruses 2011, 3, 83-101. [CrossRef]

90. Jones, S.A.; Clark, D.N.; Cao, F.; Tavis, J.E.; Hu, J. Comparative analysis of hepatitis B virus polymerase sequences required for viral RNA binding, RNA packaging, and protein priming. J. Virol. 2014, 88, 1564-1572. [CrossRef]

91. Cho, G.; Park, S.-G.; Jung, G. Localization of HSP90 Binding Sites in the Human Hepatitis B Virus Polymerase. Biochem. Biophys. Res. Commun. 2000, 269, 191-196. [CrossRef] [PubMed]

92. Wang, H.; Ryu, W.-S. Hepatitis B Virus Polymerase Blocks Pattern Recognition Receptor Signaling via Interaction with DDX3: Implications for Immune Evasion. PLoS Pathog. 2010, 6, e1000986. [CrossRef] [PubMed]

93. Park, S.G.; Jung, G. Human Hepatitis B Virus Polymerase Interacts with the Molecular Chaperonin Hsp60. J. Virol. 2001, 75, 6962-6968. [CrossRef] [PubMed]

94. Yu, S.; Chen, J.; Wu, M.; Chen, H.; Kato, N.; Yuan, Z. Hepatitis B virus polymerase inhibits RIG-I- and Toll-like receptor 3-mediated beta interferon induction in human hepatocytes through interference with interferon regulatory factor 3 activation and dampening of the interaction between TBK1/IKK and DDX3. J. Gen. Virol. 2010, 91, 2080-2090. [CrossRef]

95. Liu, Y.; Li, J.; Chen, J.; Li, Y.; Wang, W.; Du, X.; Song, W.; Zhang, W.; Lin, L.; Yuan, Z. Hepatitis B virus polymerase disrupts K63-linked ubiquitination of STING to block innate cytosolic DNA-sensing pathways. J. Virol. 2015, 89, 2287-2300. [CrossRef]

96. Zhang, J.; Hu, M.-M.; Wang, Y.-Y.; Shu, H.-B. TRIM32 Protein Modulates Type I Interferon Induction and Cellular Antiviral Response by Targeting MITA/STING Protein for K63-linked Ubiquitination*. J. Boil. Chem. 2012, 287, 28646-28655. [CrossRef]

97. Glebe, D.; Urban, S. Viral and cellular determinants involved in hepadnaviral entry. World J. Gastroenterol. 2007, 13, 22-38. [CrossRef]

98. Sun, F.-C.; Wei, S.; Li, C.-W.; Chang, Y.-S.; Chao, C.-C.; Lai, Y.-K. Localization of GRP78 to mitochondria under the unfolded protein response. Biochem. J. 2006, 396, 31-39. [CrossRef]

99. Lazăr, C.; Macovei, A.; Petrescu, S.; Branza-Nichita, N. Activation of ERAD Pathway by Human Hepatitis B Virus Modulates Viral and Subviral Particle Production. PLoS ONE 2012, 7, e34169. [CrossRef]

100. Ma, Y.; Yu, J.; Chan, H.L.Y.; Chen, Y.-C.; Wang, H.; Chen, Y.; Chan, C.-Y.; Go, M.Y.Y.; Tsai, S.-N.; Ngai, S.-M.; et al. Glucose-regulated protein 78 is an intracellular antiviral factor against hepatitis B virus. Mol. Cell. Proteom. 2009, 8, 2582-2594. [CrossRef] 
101. Cho, D.-Y.; Yang, G.-H.; Ryu, C.J.; Hong, H.J. Molecular Chaperone GRP78/BiP Interacts with the Large Surface Protein of Hepatitis B Virus In Vitro and In Vivo. J. Virol. 2003, 77, 2784-2788. [CrossRef] [PubMed]

102. Gao, Z.; Niu, X.; Zhang, Q.; Chen, H.; Gao, A.; Qi, S.; Xiang, R.; Belting, M.; Zhang, S. Mitochondria chaperone GRP75 moonlighting as a cell cycle controller to derail endocytosis provides an opportunity for nanomicrosphere intracellular delivery. Oncotarget 2017, 8, 58536-58552. [CrossRef] [PubMed]

103. Wadhwa, R. Hsp70 Family Member, mot-2/mthsp70/GRP75, Binds to the Cytoplasmic Sequestration Domain of the p53 Protein. Exp. Cell Res. 2002, 274, 246-253. [CrossRef] [PubMed]

104. Cui, L.; Ge, Y.; Qi, Y.; Shi, Z.; Jiao, Y.; Qi, X.; Zhai, X.; Wang, H. Identification of GRP75 as a novel PreS1 binding protein using a proteomics strategy. Braz. J. Microbiol. 2010, 41, 512-518. [CrossRef] [PubMed]

105. Patient, R.; Hourioux, C.; Roingeard, P. Morphogenesis of hepatitis B virus and its subviral envelope particles. Cell. Microbiol. 2009, 11, 1561-1570. [CrossRef]

106. Huovila, A.P.; Eder, A.M.; Fuller, S.D. Hepatitis B surface antigen assembles in a post-ER, pre-Golgi compartment. J. Cell Boil. 1992, 118, 1305-1320. [CrossRef]

107. Chua, P.K.; Wang, R.Y.-L.; Lin, M.-H.; Masuda, T.; Suk, F.-M.; Shih, C. Reduced Secretion of Virions and Hepatitis B Virus (HBV) Surface Antigen of a Naturally Occurring HBV Variant Correlates with the Accumulation of the Small S Envelope Protein in the Endoplasmic Reticulum and Golgi Apparatus. J. Virol. 2005, 79, 13483-13496. [CrossRef]

108. Gong, X.; Zhu, Y.; Dong, J.; Chen, J.; You, J.; Zheng, Q.; Rao, Z.; Mao, Q.; Jiang, J. Small hepatitis B surface antigen interacts with and modulates enoyl-coenzyme A hydratase expression in hepatoma cells. Arch. Virol. 2013, 158, 1065-1070. [CrossRef]

109. Xiao, C.-X.; Yang, X.-N.; Huang, Q.-W.; Zhang, Y.-Q.; Lin, B.-Y.; Liu, J.-J.; Liu, Y.-P.; Jazag, A.; Guleng, B.; Ren, J.-L. ECHS1 acts as a novel HBsAg-binding protein enhancing apoptosis through the mitochondrial pathway in HepG2 cells. Cancer Lett. 2013, 330, 67-73. [CrossRef]

110. Liu, Y.-P.; Yang, X.-N.; Jazag, A.; Pan, J.-S.; Hu, T.-H.; Liu, J.-J.; Guleng, B.; Ren, J.-L. HBsAg Inhibits the Translocation of JTB into Mitochondria in HepG2 Cells and Potentially Plays a Role in HCC Progression. PLOS ONE 2012, 7, e36914. [CrossRef]

111. Wong, N.; Chan, A.; Lee, S.-W.; Lam, E.; To, K.-F.; Lai, P.B.-S.; Li, X.-N.; Liew, C.-T.; Johnson, P.J. Positional mapping for amplified DNA sequences on 1q21-q22 in hepatocellular carcinoma indicates candidate genes over-expression. J. Hepatol. 2003, 38, 298-306. [CrossRef]

112. Holmes, K.; Shepherd, D.A.; Ashcroft, A.E.; Whelan, M.; Rowlands, D.J.; Stonehouse, N.J. Assembly Pathway of Hepatitis B Core Virus-like Particles from Genetically Fused Dimers. J. Boil. Chem. 2015, 290, 16238-16245. [CrossRef] [PubMed]

113. Zhou, S.; Standring, D.N. Hepatitis B virus capsid particles are assembled from core-protein dimer precursors. Proc. Natl. Acad. Sci. USA 1992, 89, 10046-10050. [CrossRef] [PubMed]

114. Zheng, C.L.; Fu, Y.M.; Xu, Z.X.; Zou, Y.; Deng, K. Hepatitis B virus core protein dimerdimer interface is critical for viral replication. Mol. Med. Rep. 2019, 19, 262-270. [CrossRef]

115. Syken, J.; De-Medina, T.; Münger, K. TID1, a human homolog of the Drosophila tumor suppressor 1(2)tid, encodes two mitochondrial modulators of apoptosis with opposing functions. Proc. Natl. Acad. Sci. USA 1999, 96, 8499-8504. [CrossRef] [PubMed]

116. Edwards, K.M.; Münger, K. Depletion of physiological levels of the human TID1 protein renders cancer cell lines resistant to apoptosis mediated by multiple exogenous stimuli. Oncogene 2004, 23, 8419-8431. [CrossRef] [PubMed]

117. Trentin, G.; He, Y.; Wu, D.; Tang, D.; Rozakis-Adcock, M. Identification of an hTid-1 mutation which sensitizes gliomas to apoptosis. FEBS Lett. 2004, 578, 323-330. [CrossRef] [PubMed]

118. Sohn, S.-Y.; Kim, S.-B.; Ahn, B.-Y. Negative regulation of hepatitis B virus replication by cellular Hsp40/DnaJ proteins through destabilization of viral core and X proteins. J. Gen. Virol. 2006, 87, 1883-1891. [CrossRef]

(C) 2020 by the authors. Licensee MDPI, Basel, Switzerland. This article is an open access article distributed under the terms and conditions of the Creative Commons Attribution (CC BY) license (http://creativecommons.org/licenses/by/4.0/). 